\title{
Mechanism of Natriuresis after Closure of Chronic Arteriovenous Shunts
}

\author{
Henry Mandin \\ From the Division of Internal Medicine, Faculty of Medicine, University of \\ Calgary, Calgary, Canada T2N 1N4
}

A B S T R A C T Animals subjected to certain cardiovascular manipulations, such as arteriovenous fistulas, diminish their urinary sodium excretion. It has been shown that closure of such fistulas results in a prompt increase in the rate of sodium excretion. However, the nature of the renal mechanisms increasing the excretion of sodium when the initial cardiovascular abnormality is corrected has remained unclear. Since the elucidation of such mechanisms might provide information pertinent to other sodium-retaining states, the effect of closure of chronic Teflon-Silastic arteriovenous shunts was studied in desoxycorticosterone acetate (DOCA)-treated dogs by utilizing micropuncture techniques.

Nephron filtration rates were measured first during a control period with open arteriovenous shunts and then again after closure of the shunis in 12 dogs. Nephron filtration rate rose $32 \%$ while total glomerular filtration rate (GFR) decreased $8 \%$. After closure of the arteriovenous shunt, fractional reabsorption increased $6 \%$, while total kidney filtration fraction increased from 0.31 to 0.35 . Renal plasma flow decreased from a mean of $111 \mathrm{ml} / \mathrm{min}$ to $90 \mathrm{ml} / \mathrm{min}$. Closure of the arteriovenous shunts increased sodium excretion from a mean of 21 $\mu \mathrm{eq} / \mathrm{min}$ to $45 \mu \mathrm{eq} / \mathrm{min}$. Concomitantly, a redistribution of filtrate to superficial nephrons occurred. Since pharmacological doses of DOCA were being administered while total GFR was not increased and fractional reabsorption of sodium in the proximal tubule was not inhibited, it was concluded that filtrate distribution to superficial nephrons may have contributed to the observed natriuresis, although alternate explanations were also deemed possible.

A preliminary report of this work has been presented at the meeting of the Canadian Society for Clinical Investigation, 24 January 1973, Edmonton, Canada and the Western Regional meeting of the American Federation for Clinical Research, 2 February 1973, Carmel, Calif.

Received for publication 22 February 1973 and in revised form 16 April 1973.

\section{INTRODUCTION}

In salt-retaining states the renal excretion of sodium and water may be reduced so that a small daily positive balance leads to a progressive expansion of the volume of extracellular fluid. Current knowledge of the mechanisms by which increases in renal retention of sodium replace a normal renal response to an expanded volume of extracellular fluid is far from complete. Available knowledge stems in part from studies of animals in which a natriuresis has been produced with volume expansion and in part from studies of animals in which an antinatriuresis has been produced experimentally with a variety of cardiovascular manipulations.

Utilizing volume expansion, De Wardener, Mills, Clapham, and Hayter $(1,2)$ and Levinsky and Lalone (3) established that increased sodium excretion occurred in the absence of changes in glomerular filtration rate $(\mathrm{GFR})^{1}$ and mineralocorticoid activity. The elimination of these two factors led to the postulation that other factors may play a part in sodium balance. Recent studies (4-9) have focused attention on the role of physical factors as determinants of sodium excretion. Other mechanisms that could be involved in the regulation of sodium excretion include a natriuretic hormone (1) and redistribution of filtrate among nephrons of different reabsorptive capacities (10). To date, the evidence for a natriuretic hormone remains conflicting $(11,12)$. Current micropuncture data have also failed to support the presence of redistribution of filtration in both acute and chronic volume expansion (13-21).

Utilizing cardiovascular manipulation $(15,20,22$, 23 ), accumulated evidence has indicated that the events underlying the renal retention of salt and water are also not of a singular nature. Additional information on

\footnotetext{
${ }^{1}$ Abbreziations used in this paper: $\mathrm{C}_{\mathrm{Na}_{\mathrm{a}}} / \mathrm{C}_{\mathrm{In}}$, fraction of filtered sodium appearing in the urine; DOCA, desoxycorticosterone acetate; GFR, glomerular filtration rate; $\mathrm{PAH}$, para-aminohippuric acid; TF/P, tubular fluid to plasma.
} 
these events might result from the application of micropuncture methods to the investigation of salt-retaining states. However, two critical obstacles rendered such studies difficult: first, central to any analysis of the regulation of sodium excretion is knowledge of changes in single nephron filtration rate. Changes in single nephron filtration rate are more readily interpretable if the measurements can be made in the same animal before and after an alteration in sodium excretion. Second, cardiovascular manipulations leading to chronic sodium retention usually are not reversible. Thus, comparisons within each animal are frequently impossible.

Previous studies on Korean War veterans indicated that occlusion of chronic arteriovenous fistulas resulted in prompt increases in sodium excretion (24). These patients exhibited no signs or symptoms of heart failure. Thus a similar animal model would not represent persistent salt retention, but chronic overexpansion. Nevertheless, such a model would permit the use of micropuncture methods to investigate mechanisms operative within the kidney to increase the excretion of sodium upon occlusion of the arteriovenous connection. Elucidation of such mechanisms might provide information pertinent to states in which the sodium retention is persistent. Therefore, the present stuciy was undertaken with the following aims: (a) To produce chronic arteriovenous shunts in dogs, which, when occluded, would produce a prompt natriuresis. (b) To assess the roles of GFR mineralocorticoids, proximal tubular reabsorption, and intrarenal distribution of filtrate in the production of this natriuresis.

\section{METHODS}

Acute experiments were performed on 10 control and 12 experimental dogs weighing between 17 and $26 \mathrm{~kg}$. The dogs were anesthetized with phenobarbital $(20 \mathrm{mgm} / \mathrm{kg})$. All animals were deprived of food for $24 \mathrm{~h}$ before the study, but were allowed free access to water. The 12 experimental dogs had a Teflon-Silastic shunt ${ }^{2}$ inserted into the femoral vessels of each hind limb under sterile contitions. After recovery from surgery, 5 of the 12 dogs were placed in individual metabolic cages. Each morning total daily urine volume was determined. Sodium and potassium were determined in these samples by flame photometry. All dogs received $15 \mathrm{mgm}$ of desoxycorticosterone acetate (DOCA $)^{3}$ i.m. daily. The diet was supplemented with predetermined amounts of salt so that each dog received 6 $\mathrm{meq} / \mathrm{kg} / \mathrm{day}$ of sodium as well as $20 \mathrm{meq} /$ day of potassium. Of the 10 dogs used in the control group, in early experiments dogs with bilaterally clotted shunts or sham-operated dogs were used. These did not differ from unoperated ccntrols which were used in later experiments. Control dogs were kept in similar quarters and fed the same diet. Both groups were prepared for experiments in the same manner.

\footnotetext{
2 Cobe Laboratories, Inc., Lakewood, Col.

${ }^{3}$ Supplied as Percorten, CIBA Company Ltd., Dorval, Quebec.
}

The dogs with arteriovenous fistulas were subjected to experimentation 14 days after their initial surgery. All animals were intubated with cuffed endotracheal tubes and ventilated with a Harvard Respirator."

Cannulas were inserted into two leg veins for infusions and in the brachial artery for blood pressure measurements and blood collection. Both ureters were cannulated through a suprapubic incision. The left kidney was exposed through a flank incision and the renal pedicle was gently dissected free for a distance of 2-3 inch from the hilum. The dog was then placed on a marble table with the right side down and the kidney was placed in a Plexiglas cup mounted on a steel table situated directly above the dog. $1 \mathrm{~cm}^{2}$ of capsule was removed and the surface was bathed in mineral oil at $37^{\circ} \mathrm{C}$.

Micropuncture. A priming dose of $250 \mathrm{mg} / \mathrm{kg}$ of inulin was followed by a constant infusion at a rate of $4.8 \mathrm{mg} / \mathrm{kg}$ in $1 \mathrm{ml} / \mathrm{min}$ Ringer's solution. Samples of proximal tubular fluid were obtained with sharpened micropipettes containing colored mineral oil. Each tubule was blocked with a column of mineral oil and all fluid reaching the puncture site was collected in a precisely timed interval to permit the determination of the tubular flow rate. Two types of recollection experiments were performed:

(a) In 10 experiments the experimental period was a continuation of the control hydropenic period. This comprised the control group of dogs. During the hydropenic control period, five to six tubules were punctured and at the end of each collection an adjacent tubular segment was marked with nigrosin and a map was drawn of the area to facilitate identification during the experimental period. At the completion of the period, $15 \mathrm{~min}$ was allowed to elapse before starting the experimental perior. During the experimental period each of the previously punctured tubules were repunctured at the same site. In addition to recollection samples, a similar number of new, previously unpunctured tubules were also sampled. The recollected and new samples were obtained in random order.

(b) In 12 experiments the experimental period followed the making of two small skin incisions to expose the two Teflon-Silastic stunts and clamping of the two shunts. This comprised the experimental group of dogs. In all other respects the protocol was identical to the one outlined for the control animals.

Clearances. All 22 experiments had three 15-20 min clearance periods in both the control and experimental periods. GFR was determined from clearance of inulin and renal plasma flow from the para-aminohippuric acid ( $\mathrm{PAH})$ clearance. All infusions were administered with constant infusion pumps. Plasma insulin concentration was kept at $60-100 \mathrm{mg} / 100 \mathrm{ml}$ and plasma PAH concentration at $1.5-2$ $\mathrm{mg} / 100 \mathrm{ml}$. At least $60 \mathrm{~min}$ was allowed for equilibration. PAH was determined by the method of Smith, Finkelstein, Aliminosa, Crawford, and Graber (25). Plasma and urine inulin concentrations were determined by the diphenylamine method (26). The concentration of inulin in tubular fluid was measured by the fluorometric method of Vurek and Pegram (27). Tubular fluid volume was measured in a constant-bore capillary tube of known internal diameter. Sodium and potassium concentrations in urine and plasma were measured by an Instrumentation Laboratory flame photometer. ${ }^{5}$

\footnotetext{
${ }^{+}$Harvard Apparatus Co., Inc., Millis, Mass.

${ }^{5}$ Instrumentation Laboratory, Inc., Lexington, Mass.
} 


\section{RESULTS}

Effect of recollection technique on proximal fractional reabsorption during continued hydropenia. The effect of recollection on fractional sodium reabsorption in the proximal tubule is shown in Fig. 1. Tubular fluid to plasma $(\mathrm{TF} / \mathrm{P})$ inulin ratios were measured in 40 tubules. The ratio of recollection to the initial $\mathrm{TF} / \mathrm{P}$ inulin ratio was $0.99 \pm 0.02 \mathrm{SE}$, not statistically different from 1. Therefore, the repeated puncture of the tubules during continued hydropenia did not alter $\mathrm{TF} / \mathrm{P}$ inulin ratios.

Effect of continued hydropenia on nephron filtration rates and total kidney GFR. The effect of continued hydropenia on nephron filtration rates is shown in Fig. 2 . The mean of five to six nephron filtration rates obtained during the control period were compared to the mean of six nephron filtration rates obtained during the experimental period. A total of $10 \mathrm{dogs}$ were studied. In view of our own experiences with nephron filtration rates using the recollection technique (13), only new tubules were punctured. The ratio of the experimental to control tubules was $1.01 \pm 0.03 \mathrm{SE}$, not significantly different from 1 . Therefore, during continued hydropenia with new tubules, nephron filtration rates remained unaltered.

The relationship between spontaneous alterations in total kidney filtration rate and nephron filtration rate was also analyzed. The ratio of experimental to control total kidney filtration rate is $1.00 \pm 0.06 \mathrm{SE}$. The ratio of alterations in total kidney filtration rate to nephron filtration rate is $1.01 \pm 0.05 \mathrm{SE}$. Therefore, spontaneous alterations in total filtration rate and nephron filtration rate do not result in any redistribution of filtrate to or away from superficial nephrons. Spontaneous alterations in total filtration rate are paralleled by similar alterations in nephron filtration rate.

Effects of shunting and DOCA on renal sodium excretion. The dogs did not become edematous. All animals on metabolic balance were shown to retain sodium after shunting and administration of DOCA, but the salt retention was not persistent. The extent of the retention over the 14-day period ranged from 133 to $239 \mathrm{meq}$, with an average of $163 \mathrm{meq}$ (Table I). Sodium was retained over a period of 4-5 days, and zero sodium balance was achieved from the sixth day on (Fig. 3).

The protocol of one experiment is shown in Table II. A summary of all 12 micropuncture studies after closure of the arteriovenous shunts is shown in Table III. In these studies sodium excretion increased from an average of $21 \mu \mathrm{eq} / \mathrm{min}$ during the control open-shunt period to an average of $45 \mu \mathrm{eq} / \mathrm{min}$ after closure of the shunts, while fractional excretion of sodium rose from 0.39 to $0.92(P<0.01)$. A total of 70 tubules were punctured before closure of the shunts and 61 of these

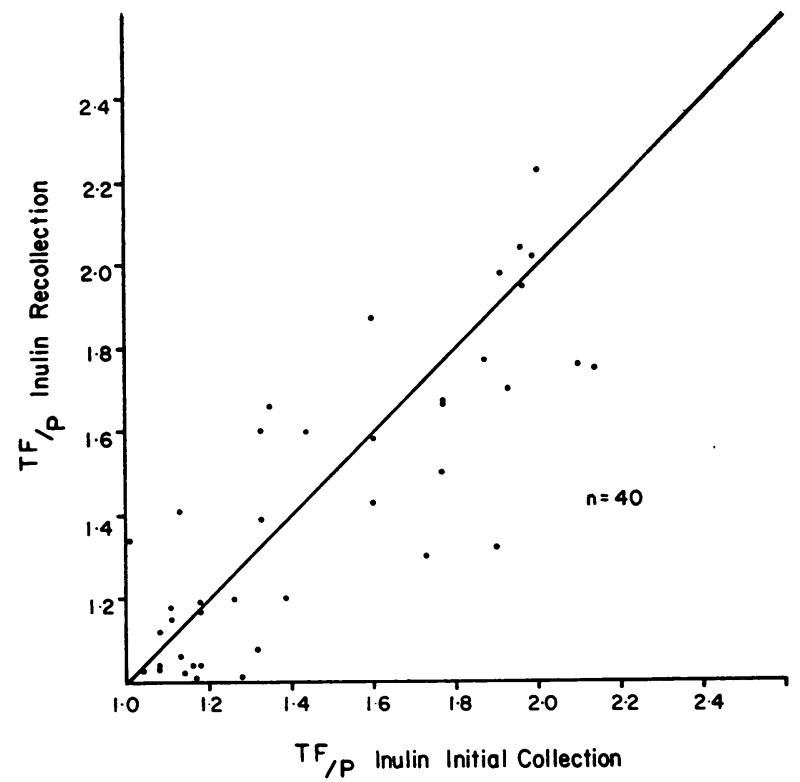

Figcre 1 Effect of tubular repuncture on fractional reabsorption in the proximal tubule during continued hydropenia. Ratio of recollection/initial collection $=0.99 \pm 0.02 \mathrm{SE}$.

could be repunctured after the shunt-clamping. There was a mean rise of $6 \%$ in $\mathrm{TF} / \mathrm{P}$ inulin ratio after clamping as shown in Fig. $4(P<0.01)$.

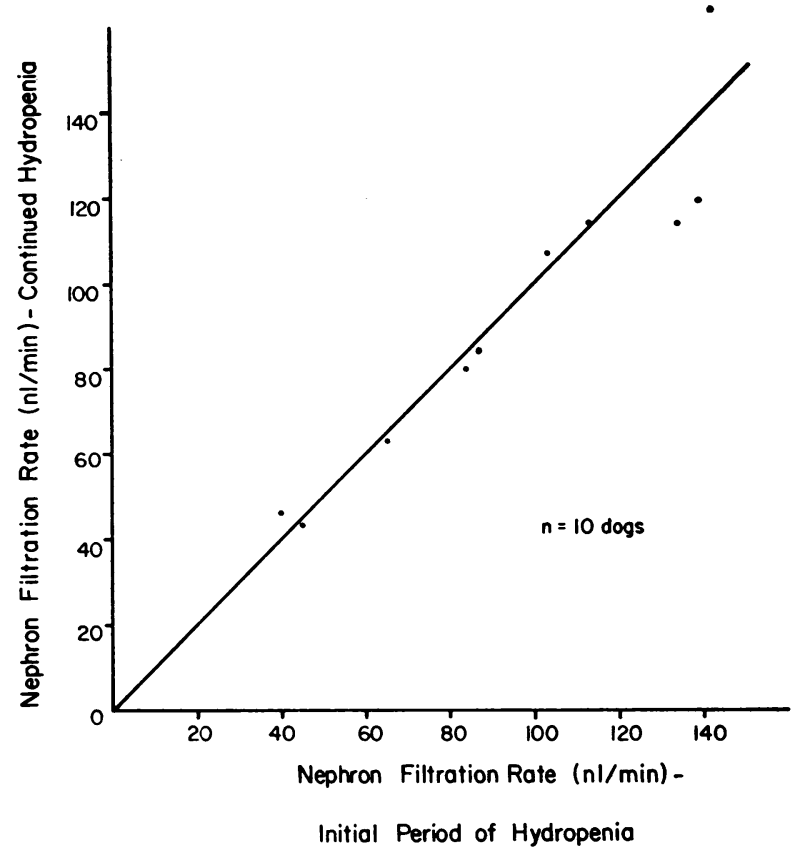

FIgURE 2 Effect of continued hydropenia on superficial nephron filtration rate. Each point represents an average of 5-6 tubules collected during two separate periods in a control dog. Ratio of second period of hydropenia/first period of hydropenia $=1.01 \pm 0.03 \mathrm{SE}$. 
TABLE I

Effect of DOCA and Shunting on Sodium Balance

\begin{tabular}{|c|c|c|c|c|c|}
\hline Dog no. & Initial wt & Final wt & $\mathrm{C}_{\mathrm{saV}}$ initial & $\mathrm{Cxa}_{\mathrm{a}} \mathrm{V}$ final & $\begin{array}{c}\text { Total } \\
\text { positive } \\
\text { sodium } \\
\text { balance }\end{array}$ \\
\hline & $\mathrm{kg}$ & $\mathrm{kg}$ & $m e q / 2+h$ & $m e q / 2+h$ & meq \\
\hline 2 & 19.0 & 19.5 & 52.3 & 107.5 & 133 \\
\hline 4 & 16.5 & 17.0 & 50.0 & 88.0 & 137 \\
\hline 6 & 17.0 & 18.3 & 29.2 & 120.5 & 173 \\
\hline 8 & 19.0 & 19.3 & 62.0 & 115.2 & 136 \\
\hline 9 & 22.0 & 22.5 & 37.5 & 123.0 & 239 \\
\hline Mean & 18.7 & 19.3 & 46.2 & 110.8 & 163 \\
\hline
\end{tabular}

$\mathrm{UsaV}$, sodium excretion.

Total GFR decreased in 10 of 12 studies, the mean decrease being $8 \%$ (Table III). Nephron filtration rate, however, increased in every one of the 12 studies with a mean increase of $32 \%$ (Fig. 5, Table III), $(P<$ $0.001)$. These changes are indicative of redistribution of filtrate to the superficial nephrons.

An analysis of the individual experiments revealed that the average nephron filtration rate increased in every experiment while total filtration rate decreased or remained unchanged. (Table III, Fig. 6). Statistical analysis of the individual experiments reveal that the increase in nephron filtration rate was significant in every experiment $(P<0.005$ in three experiments, $P<$ 0.01 in five experiments, $P<0.02$ in one experiment, $P<0.05$ in three experiments).

While total GFR decreased by an average of only

TABLE II

Protocol of a Micropuncture Experiment before and after Closure of the Arteriovenous Shunts

\begin{tabular}{|c|c|c|c|c|c|c|c|c|c|c|}
\hline Time & $\begin{array}{l}\text { Total } \\
\text { GFR }\end{array}$ & $\mathrm{RPF}$ & $\mathrm{FF}$ & $\mathrm{LxaV}$ & $\begin{array}{c}C x_{i} \\
C_{\text {Inulin }}\end{array}$ & $\mathrm{L}_{\mathrm{KV}}$ & $\begin{array}{l}\text { Tubular } \\
\text { fluid } \\
\text { sample }\end{array}$ & $\begin{array}{c}\mathrm{TF} / \\
\text { PInulin }\end{array}$ & $\begin{array}{c}\text { Nephron } \\
\text { GFR }\end{array}$ & $\begin{array}{c}\text { TF/ } \\
\text { PInulin }\end{array}$ \\
\hline & $\mathrm{ml} / \mathrm{min}$ & $m l / m i n$ & & $\mu e q / \min$ & $\%$ & $\mu e q / \min$ & & & $n l m i n$ & $c / c$ changes \\
\hline $10: 05$ & 16.3 & 66.4 & 0.25 & 13.0 & 0.5 .5 & 13.7 & 1.1 & 1.34 & 44 & \\
\hline $\begin{array}{l}10: 11 \\
10: 40\end{array}$ & & & & & & & $2 \mathrm{~A}$ & 1.19 & 26 & \\
\hline $10: 55$ & 12.3 & 54.1 & 0.2 .3 & 1.3 .2 & 0.74 & 14.0 & 3.1 & 1.1 .5 & 36 & \\
\hline $\begin{array}{l}11: 10 \\
11: 25\end{array}$ & & & & & & & & & & \\
\hline $\begin{array}{l}11: 25 \\
11: 30\end{array}$ & & & & & & & 4.1 & 1.17 & 36 & \\
\hline $\begin{array}{l}11: 30 \\
11: 35\end{array}$ & 15.3 & 59.1 & 0.26 & 10.7 & 0.48 & 12.3 & 5.1 & 1.21 & 27 & \\
\hline $\begin{array}{l}11: 35 \\
11: 45\end{array}$ & & & & & & & & & & \\
\hline $11: 45$ & & & & & & & 6.1 & 1.17 & .38 & \\
\hline Mean & 14.6 & 59.9 & 0.25 & 12.3 & 0.59 & 13.3 & & & 35 & \\
\hline \multicolumn{11}{|c|}{ Arteriovenous shunts clamped } \\
\hline $\begin{array}{l}12: 02 \\
12: 17\end{array}$ & 1.5 .4 & 46.8 & 0.33 & 36.0 & 1.61 & 22.3 & $7 A$ & 1.30 & 47 & \\
\hline $12: 22$ & & & & & & & & & & \\
\hline $12: 35$ & & & & & & & $2 \mathrm{~B}$ & 1.22 & & +3 \\
\hline $12: 40$ & & & & & & & $8 \mathrm{~A}$ & 1.25 & 43 & \\
\hline $12: 45$ & 1.3 .4 & 46.3 & 0.29 & 38.9 & 2.00 & 21.9 & $9 \mathrm{~A}$ & 1.22 & 36 & \\
\hline $12: 50$ & & & & & & & & & & \\
\hline $12: 58$ & & & & & & & $5 \mathrm{~B}$ & 1.35 & & +12 \\
\hline $1: 05$ & & & & & & & $10 \mathrm{~A}$ & 1.46 & 52 & \\
\hline $1: 09$ & 13.4 & 39.2 & 0.34 & 40.1 & 2.06 & 22.3 & $11 \mathrm{~A}$ & 1.35 & 45 & \\
\hline $1: 19$ & & & & & & & & & & \\
\hline $1: 40$ & & & & & & & $6 \mathrm{~B}$ & 1.24 & & +6 \\
\hline $1: 45$ & & & & & & & $12 \mathrm{~A}$ & 1.20 & 44 & \\
\hline Mean & 14.1 & 44.1 & 0.32 & 38.3 & 1.89 & 22.2 & & & 45 & \\
\hline $\begin{array}{l}\text { Average } \\
\% \text { change }\end{array}$ & -3 & -26 & +28 & & & & & & +29 & +7 \\
\hline
\end{tabular}

RPF, renal plasma flow; FF, filtration fraction; $\mathrm{CsaV}_{\mathrm{sa}}$; sodium excretion; $\mathrm{U}_{\mathrm{K}} \mathrm{V}$, potasium excretion. 


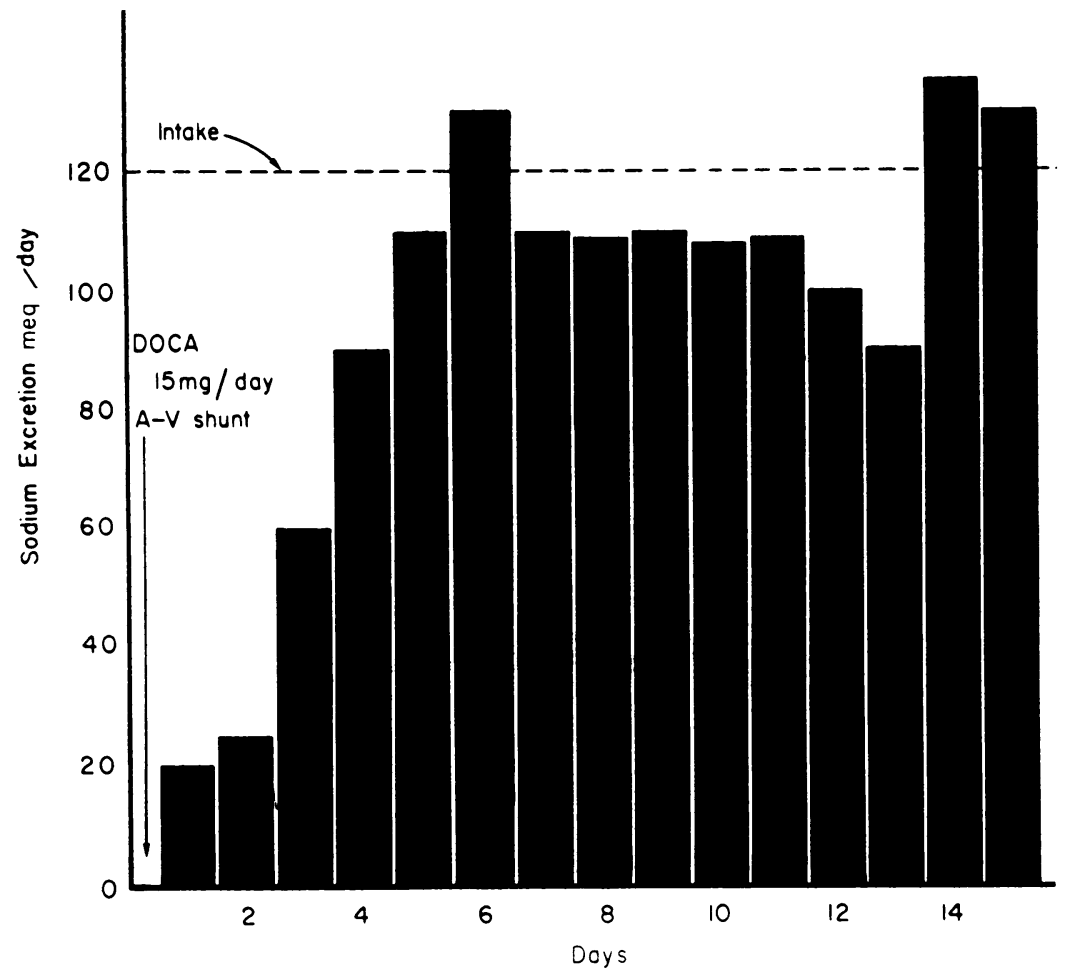

FIgLRE 3 The relationship between sodium intake and sodium excretion in a dog after the insertion of two femoral arteriovenous shunts and daily administration of 15 mom DOCA i.m.

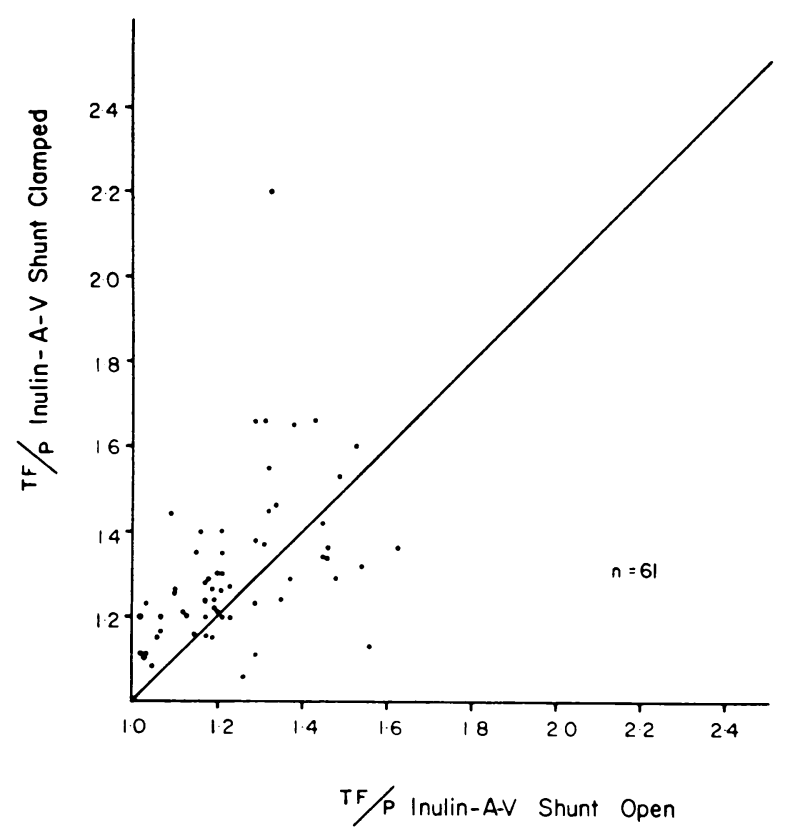

FigLre 4 Effect of closure of arteriovenous (A- $\mathrm{V}^{*}$ ) shunts on fractional reabsorption in the proximal tubule. Ratio of $\mathrm{A}-\mathrm{V}$ clamped $/ \mathrm{A}-\mathrm{V}$ open $=1.06 \pm 0.02 \mathrm{SE}$.

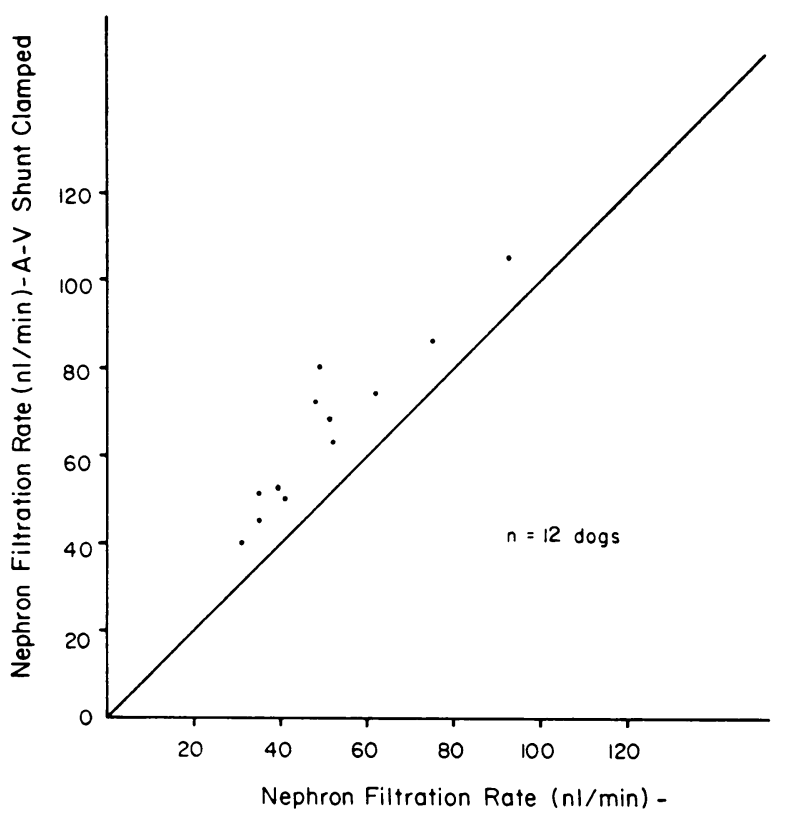

A-V Shunt Open

Figl'RE 5 Effect of closure of arteriovenous $\left(\mathrm{A}-\mathrm{V}^{-}\right)$shunts on nephron filtration rate. Ratio of $\mathrm{A}-\mathrm{V}$ clamped/A-V open $=1.32 \pm 0.04 \mathrm{SE}$. 
TABLE III

Effect of Arteriovenous Shunt Closure on Proximal Reabsorption, Nephron

\begin{tabular}{|c|c|c|c|c|c|}
\hline \multirow[b]{2}{*}{$\begin{array}{l}\text { Exp. } \\
\text { no. }\end{array}$} & \multicolumn{5}{|c|}{ Micropuncture Data } \\
\hline & $\begin{array}{l}\text { No. of } \\
\text { tubules }\end{array}$ & $\begin{array}{c}\text { Fractional } \\
\text { reabsorption } \\
\% \\
\text { change }\end{array}$ & $\begin{array}{c}\text { Nephron } \\
\text { GFR } \\
\text { O* }\end{array}$ & $\begin{array}{c}\text { Nephron } \\
\text { GFR } \\
\text { C } \ddagger\end{array}$ & $\begin{array}{c}\text { Nephron } \\
\text { GFR } \\
\% \text { changes }\end{array}$ \\
\hline & & $\%$ & $n l / \min \S$ & $n l / \min \S$ & $\%$ \\
\hline 1 & 5 & +6 & $49 \pm 7$ & $80 \pm 9$ & +63 \\
\hline 2 & 6 & 0 & $52 \pm 2$ & $63 \pm 2$ & +21 \\
\hline 3 & 5 & -8 & $62 \pm 4$ & $74 \pm 1$ & +19 \\
\hline 4 & 7 & -6 & $35 \pm 3$ & $51 \pm 5$ & +46 \\
\hline 5 & 6 & +9 & $93 \pm 6$ & $105 \pm 5$ & +13 \\
\hline 6 & 5 & -3 & $41 \pm 4$ & $50 \pm 2$ & +22 \\
\hline 7 & 6 & +7 & $35 \pm 3$ & $45 \pm 2$ & +29 \\
\hline 8 & 5 & +25 & $48 \pm 5$ & $72 \pm 6$ & +50 \\
\hline 9 & 6 & +15 & $75 \pm 4$ & $86 \pm 4$ & +15 \\
\hline 10 & 6 & +7 & $31 \pm 2$ & $40 \pm 1$ & +29 \\
\hline 11 & 7 & +5 & $51 \pm 3$ & $69 \pm 4$ & +35 \\
\hline 12 & 6 & +4 & $39 \pm 2$ & $53 \pm 3$ & +36 \\
\hline Mean & & +5 & 51 & 66 & +32 \\
\hline
\end{tabular}

* Arteriovenous shunts open.

$\ddagger$ Arteriovenous shunts clamped. $\S \pm$ SEM.

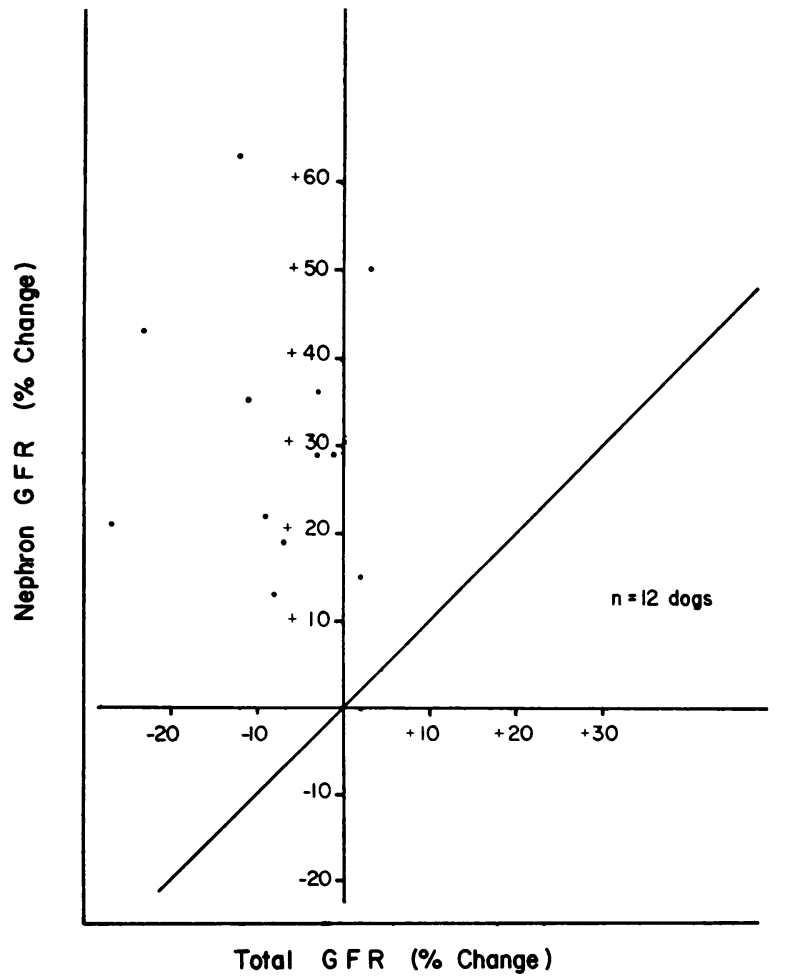

Figure 6 Comparison of percent change in nephron filtration rate to percent change in experimental kidney filtration rate. The change in nephron filtration rate is consistently higher than the change in total filtration rate.
$8 \%$, renal plasma flow decreased by an average of $19 \%$ $(P<0.01)$. A fall in renal plasma flow occurred in each experiment (Table III).

As a result of greater decrease in renal plasma flow than in total GFR, filtration fraction increased by an average of $13 \%$.

\section{DISCUSSION}

The model of arteriovenous connections made with Teflon-Silastic shunts was designed to examine with micropuncture methods the manner in which shunt closure produces a natriuresis. This became possible when the femoral Teflon-Silastic shunts were extended to a tunnel under the skin, where they were readily available for clamping and shunt closure. In addition, the occurrence of a natriuresis within $10 \mathrm{~min}$ of the shunt closure made it possible to utilize each dog as its own control.

Micropuncture studies were initiated in the shunted dogs at a time when their sodium balance was zero. Although sodium retention was limited to the first 4-5 days after shunting and DOCA administration, clamping the shunts produced an increase in sodium excretion in all dogs. The fraction of filtered sodium appearing in the urine $\left(\mathrm{C}_{\mathrm{Na}} / \mathrm{C}_{\text {In }}\right)$ (Table III) increased in all animals when flow through the shunt was prevented. In the absence of a consistent increase in the kidney inulin clearance, the increase in renal excretion of sodium might 


\begin{tabular}{|c|c|c|c|c|c|c|c|c|c|c|}
\hline & & & \multicolumn{8}{|c|}{ Clearance Data } \\
\hline \multicolumn{3}{|c|}{ Total GFR } & \multicolumn{2}{|c|}{$\begin{array}{l}\text { Renal plasma } \\
\text { flow }\end{array}$} & \multicolumn{2}{|c|}{ FF } & \multicolumn{2}{|c|}{$\mathrm{UNaV}$} & \multicolumn{2}{|c|}{$\mathrm{C}_{\mathrm{Na}} / \mathrm{C}_{\text {Inulin }}$} \\
\hline $\mathrm{O}^{*}$ & $\mathrm{C} \ddagger$ & change & $\mathrm{O}^{*}$ & $\mathrm{C} \ddagger$ & $\mathrm{O}^{*}$ & $C \ddagger$ & O* & $C \ddagger$ & $\mathrm{O}^{*}$ & $\mathrm{C} \ddagger$ \\
\hline \multicolumn{2}{|c|}{$m l / m i n$} & $\%$ & \multicolumn{2}{|c|}{$m l / m i n$} & & & \multicolumn{2}{|c|}{$\mu e q / \min$} & \multicolumn{2}{|c|}{$\%$} \\
\hline 38.6 & 34.1 & -12 & 131.7 & 92.9 & 0.29 & 0.37 & 18 & 34 & 0.36 & 0.73 \\
\hline 27.8 & 20.4 & -27 & 146.7 & 78.5 & 0.19 & 0.26 & 55 & 93 & 0.38 & 0.57 \\
\hline 26.1 & 24.3 & -7 & 141.0 & 116.8 & 0.18 & 0.21 & 22 & 57 & 0.59 & 1.63 \\
\hline 18.0 & 13.8 & -23 & 41.5 & 31.8 & 0.43 & 0.43 & 8 & 12 & 0.30 & 0.62 \\
\hline 71.0 & 65.3 & -8 & 199.5 & 182.8 & 0.35 & 0.36 & 23 & 47 & 0.23 & 0.51 \\
\hline 25.5 & 23.1 & -9 & 75.7 & 57.7 & 0.34 & 0.40 & 12 & 26 & 0.32 & 0.75 \\
\hline 14.6 & 14.1 & -3 & 59.9 & 44.1 & 0.25 & 0.32 & 12 & 38 & 0.59 & 1.89 \\
\hline 36.0 & 36.9 & +3 & 135.2 & 129.5 & 0.27 & 0.28 & 26 & 46 & 0.50 & 0.85 \\
\hline 40.0 & 40.9 & +2 & 97.3 & 89.5 & 0.42 & 0.46 & 25 & 55 & 0.41 & 0.92 \\
\hline 38.6 & 38.2 & -1 & 97.5 & 88.2 & 0.41 & 0.43 & 27 & 63 & 0.46 & 1.10 \\
\hline 28.9 & 25.7 & -11 & 94.3 & 68.9 & 0.30 & 0.37 & 18 & 47 & 0.42 & 1.02 \\
\hline 25.5 & 24.8 & -3 & 105.1 & 97.6 & 0.24 & 0.25 & 5 & 20 & 0.14 & 0.50 \\
\hline 32.6 & 30.1 & -8 & 110.5 & 89.9 & 0.31 & 0.35 & 21 & 45 & 0.39 & 0.92 \\
\hline
\end{tabular}

be construed to be the result of decreased tubular sodium reabsorption, presumably because of changes in hormonal influences or physical factors.

Since pharmacological doses of DOCA were administered to all dogs for a period of 14 days, including the day of the experiment, the postulated hormonal influences would have to be other than adrenal mineralocorticoids. Moreover, since fractional reabsorption of sodium in the proximal tubule did not diminish, such a hormone would presumably act at a more distal site in the nephron. This possibility cannot be excluded. Unfortunately, the present study offers no specific information regarding the possible presence of such a hormone.

Physical factors may be considered under two headings: compositional factors and hemodynamic factors.

Compositional alterations thought to affect sodium excretion include changes in plasma sodium concentration $(28,29)$, plasma protein concentration $(8,30)$, and hematocrit $(31,32)$. In the present study, plasma sodium concentration, plasma solids, and hematocrit were not altered by the clamping of the shunts.

Changes in renal hemodynamics may influence the reabsorption and excretion of sodium. In all of the dogs in the present study, the clamping of the shunts was accompanied by an elevation of the diastolic pressure of 5-10 mm Hg. However, the systolic pressure remained unchanged, and the increase in mean arterial pressure was small. Furthermore, the changes in sodium excre- tion could not be linearly correlated with the magnitude of the response of the blood pressure. The absence of correlation may be the result of increased vascular resistance. Earley, Martino, and Friedler $(4,6)$ clearly delineated the importance of renal vascular resistance on the effect of arterial pressure on sodium reabsorption. In the presence of a rise in mean arterial pressure of about $5 \mathrm{~mm} \mathrm{Hg}$ and a fall in renal plasma flow, renal vascular resistance increased with clamping of the shunts.

Since no measurements of protein concentration in the peritubular capillaries were obtained, we can only speculate on the changes in oncotic pressure in proximal peritubular capillaries caused by the shunt closures. Although kidney filtration fraction increased in 11 out of 12 studies, it is conceivable that superficial nephron filtration fraction did not increase. However, since superficial nephron filtration rate increased $32 \%$, superficial nephron plasma flow would also have to increase $32 \%$ to. prevent a rise in filtration fraction.

Glomerular perfusion rate was estimated to be approximately $155 \mathrm{nl} / \mathrm{min}$ in superficial nephrons and 170 $\mathrm{nl} / \mathrm{min}$ in juxtamedullary nephrons (33). If each kidney contained 13,000 glomeruli/g (34), $65 \%$ of which were superficial, a renal plasma flow of $104 \mathrm{ml} / \mathrm{min}$ could be calculated. If plasma flow to each superficial glomerulus were to increase $32 \%$, plasma flow to the superficial nephrons alone would exceed renal plasma flow. Consequently, superficial filtration fraction probably in- 
creased when the arteriovenous shunts were clamped. As a result, proximal peritubular capillary protein concentration and oncotic pressure would also increase after shunt clamping, and could represent the reason for the observed increase in fractional reabsorption of sodium in the proximal tubule (Fig. 4). This would be in agreement with the suggestion of Brenner, Falchuk, Keimowitz, and Berliner and Brenner and Troy $(8,9)$ that a correlation exists between peritubular oncotic pressure and fractional reabsorption of sodium. Moreover, since superficial nephron filtration rate increased $32 \%$, the $6 \%$ increase in fractional reabsorption of sodium represents an almost $40 \%$ increase in absolute reabsorption. Thus, at least as far as the superficial nephrons are concerned, it may be concluded that since all physical factors were unaltered or altered in a direction favoring sodium retention, the natriuresis observed cannot be explained on this basis. However, an alternate possibility does exist. Glomerular perfusion rate in juxtamedullary nephrons could have decreased less than nephron filtration rate so that filtration fraction could have fallen. Thus, the natriuresis observed could have been caused by inhibition of sodium reabsorption in juxtamedullary nephrons.

The other factor which might explain the increased sodium excretion in the present study is intrarenal distribution of glomerular filtrate to superficial nephrons, providing that this disproportionate increase in superficial nephron filtration rate results in an increased distal delivery. Although no attempt was made to identify the last convolution of the proximal tubule in the present study, comparison was possible between flow rates at identical puncture sites with the shunts patent and occluded. This comparison revealed an increase in flow rate of more than $20 \%$, so that increased distal delivery could be inferred. However, in previous studies, the occurrence of a natriuresis in the presence of increased sodium delivery from the proximal tubule was associated almost invariably with increased total GFR, diminished postglomerular protein concentration, or decreased kidney filtration fraction or all three $(8,10,30,35-38)$. Increased total GFR, decreased kidney filtration fraction, and diminished postglomerular protein concentrations could not be demonstrated or calculated in the present study. Thus, the occurrence of a natriuresis in the absence of these three factors implies either that, for some reason, the loops of Henle and distal tubules of the superficial nephrons are more easily overloaded than those of deep nephrons, or that filtration fraction and postglomerular capillary protein concentration diminished in the deep nephrons, causing inhibition of sodium reabsorption.

There are several possible explanations for the limited reabsorptive ability of the loops of Henle of superficial nephrons. A selective inhibition of tubular reabsorption of the loop of Henle of superficial nephrons as a result of the shunt-clamping appears unlikely; reabsorption of sodium from sites distal to the proximal tubule must have increased, since very little of the excess sodium presented to the distal tubule appeared in the urine. There are two other possible explanations. First, due to differences in length (39), the tubular capacity of the loop of Henle of superficial nephrons may be less than that of the deep nephrons. Second, the reabsorptive capacity of the superficial loops might be intrinsically lower per unit of length than the deeper loops.

The present study demonstrated a striking increase in superficial nephron filtration rate while kidney filtration rate fell or remained unchanged. It can be inferred that a marked filtrate redistribution to superficial nephrons occurred after closure of the arteriovenous shunts. The period of redistribution corresponded to the period of natriuresis. It may be concluded that the natriuresis caused by occlusion of chronic arteriovenous shunts is not explained by increased renal filtration rate, diminished proximal tubular sodium reabsorption in superficial nephrons, or decreased levels of mineralocorticoid activity. Hormonal or other influences on portions of the superficial nephrons distal to the proximal convoluted tubule cannot be excluded. Nor can the possibility be excluded that sodium absorption was inhibited in juxtamedullary nephrons. However, redistribution of filtrate to nephrons with a diminished capacity to reabsorb sodium may have been the cause of the observed natriuresis.

\section{ACKNOWLEDGMENTS}

The technical assistance of Miss Nancy Mitchell is gratefully acknowledged.

This work was supported by a grant of the Medical Research Council of Canada, Grant No. MA-4137.

\section{REFERENCES}

1. Mills, I. H., H. E. de Wardener, C. J. Hayter, and W. F. Clapham. 1961. Studies on the efferent mechanism of the sodium chloride diuresis which follows intravenous saline in the dog. Clin. Sci. (O.rf.). 21: 259.

2. de Wardener, H. E., I. H. Mills, W. F. Clapham, and C. J. Hayter. 1961. Studies on the efferent mechanism of the sodium diuresis which follows the administration of intravenous saline in the dog. Clin. Sci. (Oxf.). 21: 249.

3. Levinsky, N. G., and R. C. Lalone. 1963. The mechanism of sodium diuresis after saline infusion in the dog. J. Clin. Invest. 42: 1261.

4. Martino, J. A., and L. E. Earley. 1967. Demonstration of a role of physical factors as determinants of the natriuretic response to volume expansion. J. Clin. Invest. $46: 1963$.

5. Earley, L. E., J. A. Martino, and R. M. Friedler. 1966. Factors affecting sodium reabsorption by proximal tubule 
as determined during blockade of distal sodium reabsorption. J. Clin. Invest. 45: 1668.

6. Earley, L. E., and R. M. Friedler. 1966. The effects of combined renal vasodilation and pressor agents on renal hemodynamics and the tubular reabsorption of sodium. J. Clin. Invest. $45: 542$.

7. Martino, J. A., and L. E. Earley. 1968. Relationship between intrarenal hydrostatic pressure and hemodynamically induced changes in sodium excretion. Circ. Res. 23: 371 .

8. Brenner, B. M., K. H. Falchuk, R. I. Keimowitz, and R. W. Berliner. 1969. The relationship between peritubular capillary protein concentration and fluid reabsorption by the renal proximal tubule. J. Clin. Invest. 48: 1519.

9. Brenner, B. M., and J. L. Troy. 1971. Postglomerular vascular protein concentration: evidence for a causal role in governing fluid reabsorption and glomerulotubular balance by the renal proximal tubule. J. Clin. Invest. 50: 336.

10. Barger, A. C. 1966. Renal hemodynamic factors in congestive heart failure. Ann. N. Y. Acad. Sci. 139: 276.

11. Wright, F. S., B. M. Brenner, C. M. Bennett, R. I. Keimowitz, R. W. Berliner, R. W. Schrier, P. J. Verroust, $H$. De Wardener, and $H$. Holgreve. 1969. Failure to demonstrate a hormonal inhibitor of proximal sodium reabsorption. J. Clin. Invest. 48: 1107.

12. Earley, L. E., and T. M. Daugharty. 1969. Sodium metabolism. N. Engl. J. Med. 281: 72 .

13. Mandin, H., A. H. Israelit, F. C. Rector, Jr., and D. W. Seldin. 1971. Effect of saline infusion on intrarenal distribution of glomerular filtrate and proximal reabsorption in the dog. J. Clin. Invest. 50: 514.

14. Stein, J. H., R. W. Osgood, and T. F. Ferris. 1972. Effect of volume expansion on distribution of glomerular filtrate and renal cortical blood flow in the dog. $\mathrm{Am}$. J. Physiol. 223 : 984.

15. Auld, R. B., E. A. Alexander, and N. G. Levinsky. 1971. Proximal tubular function in dogs with thoracic caval constriction. J. Clin. Invest. 50: 2150.

16. Schneider, E. G., R. E. Lynch, T. P. Dresser, and F. G. Knox. 1970. Effect of saline infusion on superficial nephron filtration rate in the dog. Physiologist. 13: 303.

17. Carriere, S., P. Boulet, A. Mathieu, and M. G. Brunette. 1972. Isotonic saline loading and intrarenal distribution of glomerular filtration in dogs. Kidney Int. 2: 191.

18. Brenner, B. M., and R. W. Berliner. 1969. Relationship between extracellular volume and fluid reabsorption by the rat nephron. Am. J. Physiol. 217: 6 .

19. Bartoli, E., and L. E. Earley. 1971. The relative contributions of reabsorptive rate and redistributed nephron filtration rate to changes in proximal tubular fractional reabsorption during acute saline infusion and aortic constriction in the rat. J. Clin. Invest. 50: 2191.

20. Levy, M. 1971. Effects of acute volume expansion and altered hemodynamics on renal tubular function in chronic caval dogs. J. Clin. Invest. 51: 922.

21. Kischinski, W., M. Wahl, P. Wunderich, and K. Thurau. 1970. Different correlations between plasma protein concentration and proximal fractional reabsorption in the rat during acute and chronic saline infusion. Pflügers Archiv. Eur. J. Physiol. 321: 102.
22. Schneider, E. G., T. P. Dresser, R. E. Lynch, and F. G. Knox. 1970. Sodium reabsorption by the proximal tubule of dogs with an aorta to vena cava (A-V) fistula. Clin. Res. 18: 515. (Abstr.)

23. Gill, J. R., Jr. 1970. Edema. Annu. Rev. Med. 21 : 269.

24. Epstein, F. H., R. S. Post, and M. McDowell. 1953. The effect of an arteriovenous fistula on renal hemodynamics and electrolyte excretion. J. Clin. Invest. 32: 233.

25. Smith, H. W., N. Finkelstein, L. Aliminosa, B. Crawford, and M. Graber. 1945. The renal clearances of substituted hippuric acid derivatives and other aromatic acids in dog and man. J. Clin. Invest. 24: 388.

26. Walser, M., D. G. Davidson, and J. Orloff. 1955. The renal clearance of alkali-stable inulin. J. Clin. Invest. $34: 1520$.

27. Vurek, G. G., and S. E. Pegram. 1966. Fluorometric method for the determination of renogram quantities of inulin. Anal. Biochem. 16: 409.

28. Kamm, D. E., and N. G. Levinsky. 1964. Effect of plasma sodium elevation on renal sodium reabsorption. Am. J. Physiol. 206: 1131.

29. Kamm, D. E., and N. G. Levinsky. 1965. Inhibition of renal tubular sodium reabsorption by hypernatremia. J. Clin. Invest. 44: 1144.

30. Howards, S. S., B. B. Davis, F. G. Knox, F. S. Wright, and R. W. Berliner. 1968. Depression of fractional sodium reabsorption by the proximal tubule of the dog without sodium diuresis. J. Clin. Invest. 47: 1561.

31. Schrier, R. W., and L. E. Earley. 1970. Effects of hematocrit on renal hemodynamics and sodium excretion in hydropenic and volume-expanded dogs. J. Clin. Invest. $49: 1656$.

32. Knox, F. G., S. S. Howards, F. S. Wright, B. B. Davis, and R. W. Berliner. 1968. Effect of dilution and expansion of blood volume on proximal sodium reabsorption. Am. J. Physiol. 215: 1041.

33. Wallin, J. D., F. C. Rector, Jr., and D. W. Seldin. 1971. Measurement of intrarenal plasma flow with antiglomerular basement-membrane antibody. Am. J. Physiol. 221: 1621 .

34. Kunkel, P. A., Jr. 1930. The number and size of the glomeruli in the kidney of several mammals. Bull. Johns Hopkins Hosp. 47 : 285.

35. Daugharty, T. M., I. F. Ueki, D. P. Nicholas, and B. M. Brenner. 1972. Comparative renal effects of isotonic and colloid-free volume expansion in the rat. Am. J. Physiol. 222: 225

36. Daugharty, T. M., I. F. Ueki, D. P. Nicholas, and B. M. Brenner. 1973. Renal response to chronic intravenous salt-loading in the rat. 1973. J. Clin. Invest. 52: 21.

37. Stein, J. H., R. C. Congbalay, D. L. Karsh, R. W. Osgood, and T. F. Ferris. 1972. The effect of bradykinin on proximal tubular reabsorption in the dog: evidence for functional nephron heterogeneity. J. Clin. Invest. $51: 1709$.

38. Stein, J. H., J. H. Reineck, R. W. Osgood, and T. F. Ferris. 1971. Effect of acetylcholine on proximal tubular sodium reabsorption in the dog. Am. J. Physiol. 220: 227.

39. Sperber, I. 1944. Studies on the mammalian kidney. Zool. Bidr. Upps. 22 : 249. 